Adsorpsi Congo Red ...(Roy Andreas dan Tien S)

\title{
ADSORPSI CONGO RED PADA HUMIN HASIL ISOLASI DARI TANAH HUTAN DAMAR BATURRADEN PURWOKERTO
}

\author{
Roy Andreas dan Tien Setyaningtyas \\ Prodi Kimia, Fakultas Sains dan Teknik UNSOED \\ Purwokerto
}

\begin{abstract}
Congo red is one of dyes-stuff in textile industry wastwater. If it is thrown directly without waste management process, the dyes could pollute environtment, especially soil. Humin has $\mathrm{OH}$ phenolic and carboxylic functional group which can interacted with congo red. The aim of this study is recognize humin characteristic from the soil of Baturraden resin forest, determine the adsorption capacity and isotherm adsorption pattern of congo red by humin from the soil of Baturraden resin forest. Humin in this study is isolated from the soil of Baturraden resin forest. soil cleared of gravel and dirt, then it extracted by using $\mathrm{NaOH}$ of nitrogen atmosphere and purified to applies mixture $\mathrm{HCl}: \mathrm{HF}$. Humin that is obtained is used to be interacted with dyes with various contact time, various of $\mathrm{pH}$ and concentration of congo red so that the adsorption capacities and isotherm adsorption pattern can be obtained. Result of the study showed that the humin has water content $34.92 \%$, dust content $8.64 \%$, total acidity $475 \mathrm{cmol} / \mathrm{Kg}$, carboxylic rate $272.5 \mathrm{cmol} / \mathrm{Kg}$, and $\mathrm{OH}$ Phenolic rate $202.5 \mathrm{cmol} / \mathrm{Kg}$. The optimum contact time of congo red adsorption by humin is 40 minutes, with optimum $\mathrm{pH}$ is 7 , adsorption capacities $57.14 \mathrm{mg} / \mathrm{g}$ and isotherm adsorption pattern of congo red by humin is follow the pattern of Langmuir isotherm adsorption.
\end{abstract}

Key word: congo red, humin, adsorption

\section{PENDAHULUAN}

Masalah lingkungan yang berhubungan dengan kegiatan industri tekstil sebagian besar diakibatkan penggunaan zat warna yang bersifat organik. Sebagian senyawa-senyawa organik tersebut sulit untuk diuraikan, serta bersifat karsinogen (Suwarsa, 1998). Perubahan warna oleh air limbah masih menjadi masalah yang besar bagi lingkungan karena zat warna tersebut sulit untuk diuraikan secara alami oleh badan air penerima. Salah satu zat warna yang banyak digunakan dalam industri tekstil adalah congo red.

Congo red dalam industri tekstil biasanya digunakan sebagai pewarna merah terutama pada kain jenis katun. Senyawa ini termasuk dalam golongan pewarna diazo. Pewarna ini dapat larut dalam air menghasilkan larutan berwarna merah. Zat warna tersebut apabila dibuang langsung tanpa melalui proses pengolahan limbah dapat mengakibatkan pencemaran lingkungan, terutama tanah karena 
dalam tanah terdapat senyawasenyawa organik yang mengandung gugus fungsi yang dapat berikatan dengan zat warna congo red.

Humin merupakan komponen terbesar yang terdapat di dalam bahan humat. Humin sebagai penyusun bahan humat jumlahnya sekitar $60 \%$ dari bahan humat. Humin memiliki gugus aktif berupa - $\mathrm{COOH}$, - $\mathrm{OH}$ yang memiliki kemampuan mengadsorpsi zat warna congo red. Berdasarkan pernyataan tersebut, maka perlu dilakukan penelitian mengenai karakterisasi humin dari tanah hutan damar Baturaden dan mengetahui daya adsorpsi terhadap zat warna congo red.

\section{METODE PENELITIAN}

\section{Bahan}

Bahan-bahan yang digunakan dalam penelitian ini adalah tanah hutan damar Desa Ketenger Kecamatan Baturraden, $\mathrm{NaOH}, \mathrm{HCl}$, gas $\mathrm{N}_{2}$, campuran $\mathrm{HF}$ dengan $\mathrm{HCl}$, $\mathrm{Ba}(\mathrm{OH})_{2} .8 \mathrm{H}_{2} \mathrm{O}, \quad \mathrm{Ba}\left(\mathrm{CH}_{3} \mathrm{COO}\right)_{2}$, zat warna congo red, akuades.

Alat

Alat-alat yang digunakan adalah spektrofotometer UV-Vis, alatalat gelas, shaker, furnace, alat titrasi, pH meter, ayakan 200 mesh, oven, desikator vakum, kertas saring dan IR Shimadzhu FTIR-8201PC.

\section{Prosedur}

\section{Karakterisasi humin ( Tan, 1993)}

Prosedur penetapan kadar air dan kadar abu humin.

Lima puluh miligram humin tanpa pemurnian dan dengan pemurnian masing masing dimasukan ke dalam cawan porselin dan dipanaskan dalam oven pada suhu $110^{\circ} \mathrm{C}$ selama 24 jam. Kemudian berat sebelum dipanaskan dan setelah dipanaskan dicatat. Humin bebas air dipanaskan dengan tungku furnace pada temperatur $450^{\circ} \mathrm{C}$ selama 8 jam, berat sampel sebelum dan sesudah dipanaskan dicatat. Masing masing dilakukan dengan 2 kali perlakuan (duplo).

\section{Penetapan keasaman total.}

Sebanyak $20 \mathrm{mg}$ humin dimasukan ke dalam erlenmeyer dan ditambahkan $10 \mathrm{~mL}$ larutan $\mathrm{Ba}(\mathrm{OH})_{2}$ $0,2 \mathrm{~N}$ dalam kondisi atmosfer nitrogen. Dalam waktu yang sama juga dilakukan terhadap larutan blangko yaitu larutan jenuh $\mathrm{Ba}(\mathrm{OH})_{2} \quad 0,2 \mathrm{~N}$ sebanyak $10 \mathrm{~mL}$. Suspensi yang terbentuk disaring kemudian residu dibilas dengan aquades bebas $\mathrm{CO}_{2}$, filtrat dan air bilasan digabung lalu dititrasi secara potensiometri dengan larutan standar $\mathrm{HCl} \mathrm{0,2} \mathrm{N}$ hingga $\mathrm{pH}$ 8,4 .

Penetapan kandungan gugus karboksilat.

Sebanyak 20 mg humin dimasukkan ke dalam erlenmeyer dan ditambahkan $10 \mathrm{~mL}$ larutan $\mathrm{Ba}\left(\mathrm{CH}_{3} \mathrm{COO}\right)_{2} \quad 0,2 \mathrm{M}$ dan $40 \mathrm{~mL}$ aquades bebas $\mathrm{CO}_{2}$. Dalam waktu yang sama juga dilakukan terhadap larutan blangko yaitu $10 \mathrm{~mL}$ larutan $\mathrm{Ba}\left(\mathrm{CH}_{3} \mathrm{COO}\right)_{2} \quad 0,2 \mathrm{M}$ dan $40 \mathrm{~mL}$ destilat bebas $\mathrm{CO}_{2}$ kemudian larutan dishaker selama 24 jam pada suhu kamar. Suspensi yang terbentuk disaring kemudian residu dibilas dengan air destilat bebas $\mathrm{CO}_{2}$. Filtrat dan air bilasan digabung, kemudian dititrasi dengan menggunakan larutan 
standar $0,01 \mathrm{M} \mathrm{NaOH}$ hingga $\mathrm{pH} 9,8$ kandungan gugus karboksilat dapat dihitung dengan persamaan:

$$
\text { Gugus }-\mathrm{COOH}(\mathrm{cmol} / \mathrm{Kg})=\frac{(\mathrm{Vs}-\mathrm{Vb}) \times \mathrm{N} \times 10^{5}}{\text { berat sampel }(\mathrm{mg})}
$$

Dimana:

$\mathrm{Vb}=$ volume $\mathrm{NaOH}$ yang digunakan untuk mentitrasi blangko

$\mathrm{Vs}=$ volume $\mathrm{NaOH}$ yang digunakan untuk mentitrasi sampel

$\mathrm{N}=$ normalitas larutan standar basa

\section{Penetapan kandungan gugus $\mathrm{OH}$ fenolat.}

Kandungan gugus fungsional humin yang ditentukan adalah gugus karboksilat $(-\mathrm{COOH})$ dan $-\mathrm{OH}$ fenolat. Gugus - $\mathrm{OH}$ fenolat dapat ditentukan dengan menghitung selisih antara keasaman total dengan kandungan gugus $-\mathrm{COOH}$.

\section{OH fenol = keasaman total - kandungan $\mathrm{COOH}$}

Identifikasi gugus fungsional humin. Humin kotor dan humin yang telah dimurnikan dikarakterisasi menggunakan metode spektroskopi infra merah untuk mengetahui gugus fungsinya

\section{Adsorpsi Congo Red pada Humin}

Penentuan waktu kontak optimum

Sebanyak 0,02 gram humin dalam $25 \mathrm{~mL}$ larutan congo red 20 $\mathrm{mg} / \mathrm{L}$, diatur pada $\mathrm{pH} 7$ dengan penambahan buffer phospat, kemudian dikocok dengan variasi waktu kontak $2,10,20,40,60,90,120,150$, dan 180 menit. larutan kemudian disaring, filtrat yang dihasilkan diukur absorbansinya pada panjang gelombang maksimum dengan spektrofotometer UV-Vis. Banyaknya congo red yang terserap merupakan selisih konsentrasi awal dan akhir congo red.

\section{Penentuan pH optimum}

Sebanyak 0,02 gram humin dikocok pada $25 \mathrm{~mL}$ larutan congo red $20 \mathrm{mg} / \mathrm{L}$, pada waktu kontak setimbang, diujikan pada variasi $\mathrm{pH} 5$, 6 ,7 ,8 dan 9. Kemudian diukur absorbansinya pada panjang gelombang maksimum dengan spektrofotometer UV-Vis. Dibuat kurva hubungan antara absorbansi dengan $\mathrm{pH}$.

\section{Penentuan pola isoterm adsorpsi}

Sebanyak 0,02 gram humin ditambah pada $25 \mathrm{~mL}$ larutan congo red dengan variasi konsentrasi congo red 5, 10, 20, 40, 60, 80, 100, 120, 140, 160, 180, 200, 220, 240, 260, 280 dan $300 \mathrm{mg} / \mathrm{L}$, dikocok pada waktu kontak setimbang dan $\mathrm{pH}$ optimum. Larutan kemudian disaring, filtrat yang dihasilkan diukur absorbansinya pada panjang gelombang maksimum dengan spektrofotometer UV-Vis, kemudian ditentukan kapasitas penyerapannya.

\section{HASIL DAN PEMBAHASAN Karakteristik Humin}

Hasil analisis FTIR humin sebelum dimurnikan dapat dilihat pada Gambar 1, dan sesudah dimurnikan humin dapat dilihat pada Gambar 2. Terdapat beberapa perbedaan antara humin sebelum dimurnikan dan humin sesudah dimurnikan. Humin sebelum dimurnikan mempunyai serapan pada 
Molekul, Vol. 3. No. 1. Mei, 2008 : 1 - 9

bilangan gelombang antara 1300-1500 $\mathrm{cm}^{-1}$ dan serapan pada bilangan gelombang $1099,3 \mathrm{~cm}^{-1}$ yang tidak terdapat pada humin yang sudah dimurnikan serta munculnya serapan pada bilangan gelombang $617,2 \mathrm{~cm}^{-1}$ pada humin yang sudah dimurnikan yang tidak tampak pada humin sebelum dimurnikan.

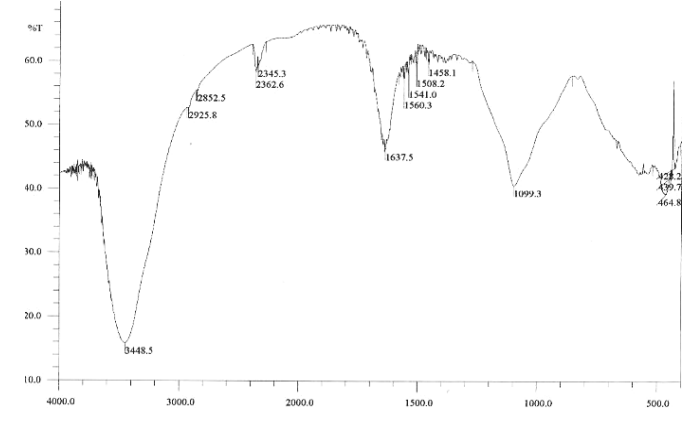

Gambar 1. Spektrum IR humin sebelum dimurnikan

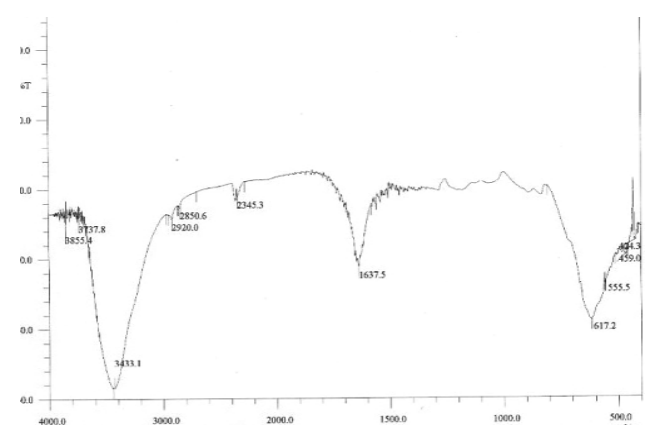

Gambar 2. Spektrum IR humin sesudah dimurnikan

Berdasarkan Gambar 1 dan Gambar 2 terdapat serapan pada bilangan gelombang antara 1300 $1550 \mathrm{~cm}^{-1}$ pada humin sebelum pemurnian sedangkan pada humin murni tidak terdapat serapan pada bilangan gelombang tersebut. Menurut Tan (1993) adanya mineral logam pada humin akan menyebabkan munculnya serapan tajam pada bilangan gelombang $1300-1500 \mathrm{~cm}^{-1}$ yang teridentifikasi berasal dari vibrasi ulur $\mathrm{C}-\mathrm{O}$ dalam gugus karboksilat yang terdapat dalam bentuk anion $\mathrm{COO}^{-}$. Dengan demikian proses pemurnian humin dapat ditafsirkan sebagai pelepasan ion-ion logam yang terikat pada humin yang mengakibatkan terjadinya konversi dari gugus $-\mathrm{COO}^{-}$menjadi gugus $\mathrm{COOH}$. Proses ini akan menyebabkan hilangnya pita serapan disekitar 1500 $1300 \mathrm{~cm}^{-1}$.

Perbedaan antara humin kotor dan murni adalah adanya serapan pada bilangan gelombang $1099,3 \mathrm{~cm}^{-1}$ yang tidak terlihat pada spektrum IR humin murni. Menurut Tan (1982) adanya serapan pada bilangan gelombang antara $950-1170 \mathrm{~cm}^{-1}$ disebabkan $\mathrm{SiO}_{2}$, sedangkan pada humin murni serapan pada bilangan gelombang 1099,3 $\mathrm{cm}^{-1}$ tidak ada, hal ini disebabkan oleh menurunnya kadar $\mathrm{SiO}_{2}$.

Munculnya serapan pada bilangan gelombang $617,2 \mathrm{~cm}^{-1}$ pada humin setelah pemurnian disebabkan terbentuknya ikatan C-Cl. Ikatan C-Cl diakibatkan kontaminasi $\mathrm{Cl}$ yang berasal dari pemurnian menggunakan campuran $\mathrm{HF}: \mathrm{HCl}$.

Gugus - $\mathrm{OH}$ fenolat ataupun $\mathrm{OH}$ alkoholat terlihat pada pita serapan dengan bilangan gelombang $3433,1 \mathrm{~cm}^{-1}$ yang berasal dari vibrasi ulur -OH, bilangan gelombang 2920,0 $\mathrm{cm}^{-1}$ dan 2850,6 $\mathrm{cm}^{-1}$ merupakan vibrasi ulur $\mathrm{C}-\mathrm{H}$ alifatik dan bilangan gelombang $2345,3 \mathrm{~cm}^{-1}$ menunjukkan adanya $\mathrm{OH}$ ikatan hidrogen. Bilangan gelombang $1637,5 \mathrm{~cm}^{-1}$ diperkirakan merupakan vibrasi ulur $\mathrm{C}=\mathrm{C}$ aromatic 
atau $\mathrm{H}$ yang terikat pada $\mathrm{C}=\mathrm{O}$ (keton terkonjugasi), ikatan rangkap terkonjugasi dengan karbonil dan vibrasi $\mathrm{COO}^{-}$.

\section{Penentuan kadar air dan kadar abu}

Kadar air bahan adalah jumlah air bebas yang terkandung di dalam bahan yang dapat dipisahkan dengan cara fisis seperti penguapan, sedangkan kadar abu suatu bahan adalah kadar residu hasil pembakaran semua komponen-komponen organik di dalam bahan yang biasanya berupa mineral (SNI 13-6793, 2002).

Kadar air dan abu pada humin dari tanah hutan damar Desa Ketenger Kecamatan Baturaden dapat dilihat pada Tabel 1.

Tabel 1. Kadar air dan kadar abu humin hasil isolasi

\begin{tabular}{cccc}
\hline No & Humin & $\begin{array}{c}\text { Kadar air } \\
(\%)\end{array}$ & $\begin{array}{c}\text { Kadar } \\
\text { Abu } \\
(\%)\end{array}$ \\
\hline 1 & Kotor & 40,26 & 41,80 \\
2 & Murni & 34,92 & 8,64 \\
\hline
\end{tabular}

Humin kotor dan humin murni mempunyai nilai kadar air yang tidak berbeda secara signifikan, yaitu 40,26 $\%$ untuk humin kotor dan 34,92 \% untuk humin murni. Nilai kadar abu humin kotor yaitu 41,80 \% sedangkan nilai kadar abu setelah dimurnikan sebesar $8,64 \%$.

\section{Penentuan Gugus Fungsional}

Keasaman total atau kapasitas tukar senyawa-senyawa humat tanah dikarenakan oleh kehadiran proton atau ion-ion $\mathrm{H}^{+}$pada gugus-gugus karboksil aromatik dan gugus hidroksil fenolat (Tan, 1995). Tabel 2 menunjukkan keasaman total, kandungan gugus karboksilat dan hidroksil fenolat humin dari tanah hutan damar Desa Ketenger Kecamatan Baturaden

Tabel 2. Kandungan gugus fungsional humin hasil isolasi

\begin{tabular}{|c|c|c|}
\hline No & $\begin{array}{c}\text { Gugus } \\
\text { Fungsional }\end{array}$ & $\begin{array}{c}\text { Kandungan } \\
\text { (cmol/kg) }\end{array}$ \\
\hline 1 & $\begin{array}{c}\text { Keasaman } \\
\text { total }\end{array}$ & 475 \\
\hline 2 & Karboksilat & 202,5 \\
\hline 3 & $\mathrm{OH}$ fenolat & 272,5 \\
\hline
\end{tabular}

Tabel 2 menunjukkan keasaman total humin adalah sebesar $475 \mathrm{cmol} / \mathrm{kg}$, dengan kandungan karboksilat sebesar $202,5 \mathrm{cmol} / \mathrm{kg}$ dan $\mathrm{OH}$ fenolat sebesar $272,2 \mathrm{cmol} / \mathrm{kg}$. Rendahnya gugus karboksilat terlihat dengan lemahnya serapan pada daerah $1700 \mathrm{~cm}^{-1}$ pada spektra IR sedangkan kandungan $\mathrm{OH}$ fenolat lebih tinggi daripada gugus karboksilat, hal ini diperkuat dengan adanya serapan yang cukup kuat pada daerah $3433,1 \mathrm{~cm}^{-1}$.

\section{Adsorpsi Zat Warna Congo Red oleh Humin}

\section{Penentuan waktu kontak optimum}

Waktu kontak optimum adalah waktu yang dibutuhkan untuk interaksi antara humin dengan congo red sehingga menghasilkan adsorpsi maksimum. Hasilnya dapat dilihat pada Gambar 3. 
Molekul, Vol. 3. No. 1. Mei, 2008 : 1 - 9

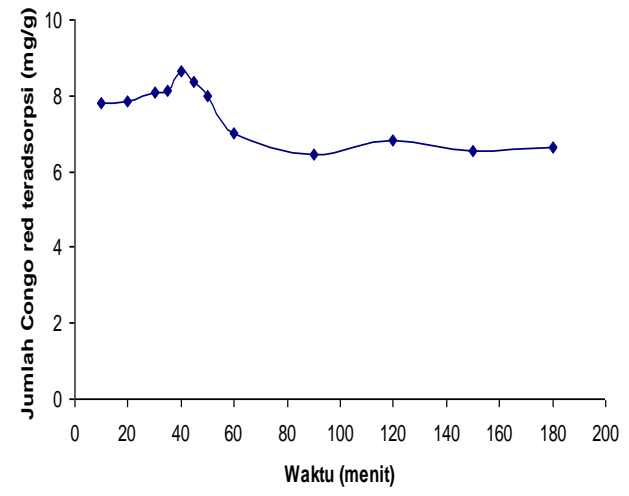

Gambar 3. Penentuan waktu kontak optimum

Gambar 3 menunjukkan bahwa pada menit ke 10 telah terjadi proses adsorpsi dan terus terjadi peningkatan hingga menit ke 40. Pada menit ke 40, proses adsorpsi telah maksimum. Hal tersebut dapat dilihat dari grafik yang mencapai titik optimum. Proses adsorpsi terjadi ketika gugus fungsional humin berinteraksi dengan congo red. Kemudian terjadi penurunan jumlah congo red yang teradsorpsi pada menit ke 40 hingga pada menit ke 90. Hal ini terjadi karena congo red yang terikat oleh gugus fungsional humin terlepas akibat pengocokkan. Setelah menit ke 90 jumlah adsorpsi cenderung konstan dan ini menunjukkan bahwa pada menit ke 90 terjadi kesetimbangan adsorpsi.

\section{Penentuan pH optimum}

Congo red merupakan indikator asam basa sehingga dapat mengalami perubahan warna mencolok dalam larutan apabila $\mathrm{pH}$ larutan berubah. Pengaruh $\mathrm{pH}$ dalam penyerapan larutan congo red oleh humin dapat dilihat dalam Gambar 4.

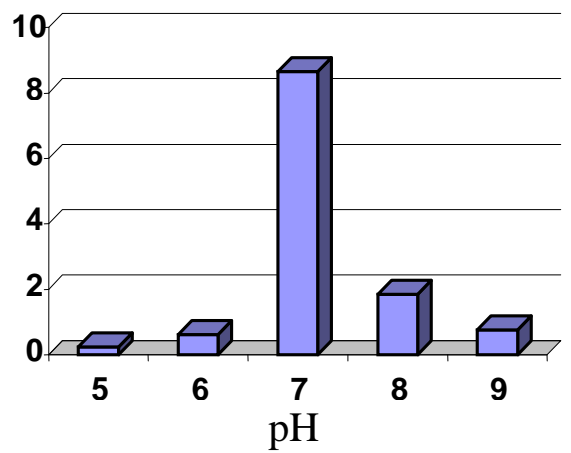

Gambar 4. Penentuan $\mathrm{pH}$ optimum adsorpsi congo red oleh humin

Gambar 4 menunjukkan bahwa $\mathrm{pH}$ optimum untuk penyerapan congo red oleh humin tercapai pada $\mathrm{pH} 7$, ditandai dengan jumlah congo red yang terserap paling besar dibanding pada $\mathrm{pH}$ yang lain. Menurut Allen and Koumanova (2005) pH sangat berpengaruh dalam proses adsorpsi. Gugus $-\mathrm{SO}_{3} \mathrm{Na}$ pada congo red dalam suasana basa akan terpecah menjadi $\mathrm{SO}_{3}{ }^{-}$dan $\mathrm{Na}^{+}$, sedangkan gugus $\mathrm{COOH}$ ataupun $\mathrm{OH}$ fenolat yang berasal dari gugus aktif humin cenderung melepas proton pada suasana basa membentuk $\mathrm{COO}^{-}$dan $\mathrm{RO}^{-}$. Hal ini menyebabkan gugus $-\mathrm{SO}_{3}$ pada congo red akan sukar berinteraksi dengan $\mathrm{COO}^{-}$dan $\mathrm{RO}^{-}$. 


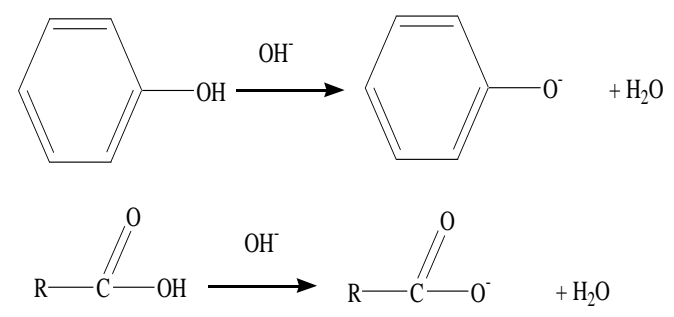

Gambar 5. Gugus aktif humin pada suasana basa.

Interaksi congo red pada suasana asam terjadi protonasi gugus $\mathrm{NH}_{2}$ pada congo red menghasilkan $\mathrm{NH}_{3}{ }^{+}$yang akan distabilkan oleh gugus aromatik melalui proses delokalisasi elektron.
Humin pada suasana asam akan sukar melepaskan $\mathrm{H}^{+}$pada gugus $\mathrm{COOH}$ ataupun $\mathrm{OH}$ fenolat sehingga sukar untuk membentuk $\mathrm{COO}^{-}$dan $\mathrm{RO}^{-}$. Hal ini menyebabkan gugus $\mathrm{COOH}$ ataupun $\mathrm{OH}$ fenolat sulit berinteraksi dengan congo red yang terprotonasi.

Interaksi humin dengan congo red pada $\mathrm{pH} 7$ akan terjadi penyerapan maksimum. Interaksi humin pada $\mathrm{pH} 7$ disebabkan oleh terjadinya ikatan hidrogen antara gugus karboksilat dan fenolat pada humin dengan gugus amina pada congo red (Vinod et. al., 2003). Mekanisme terjadinya ikatan hidrogen dapat terlihat pada Gambar 6.

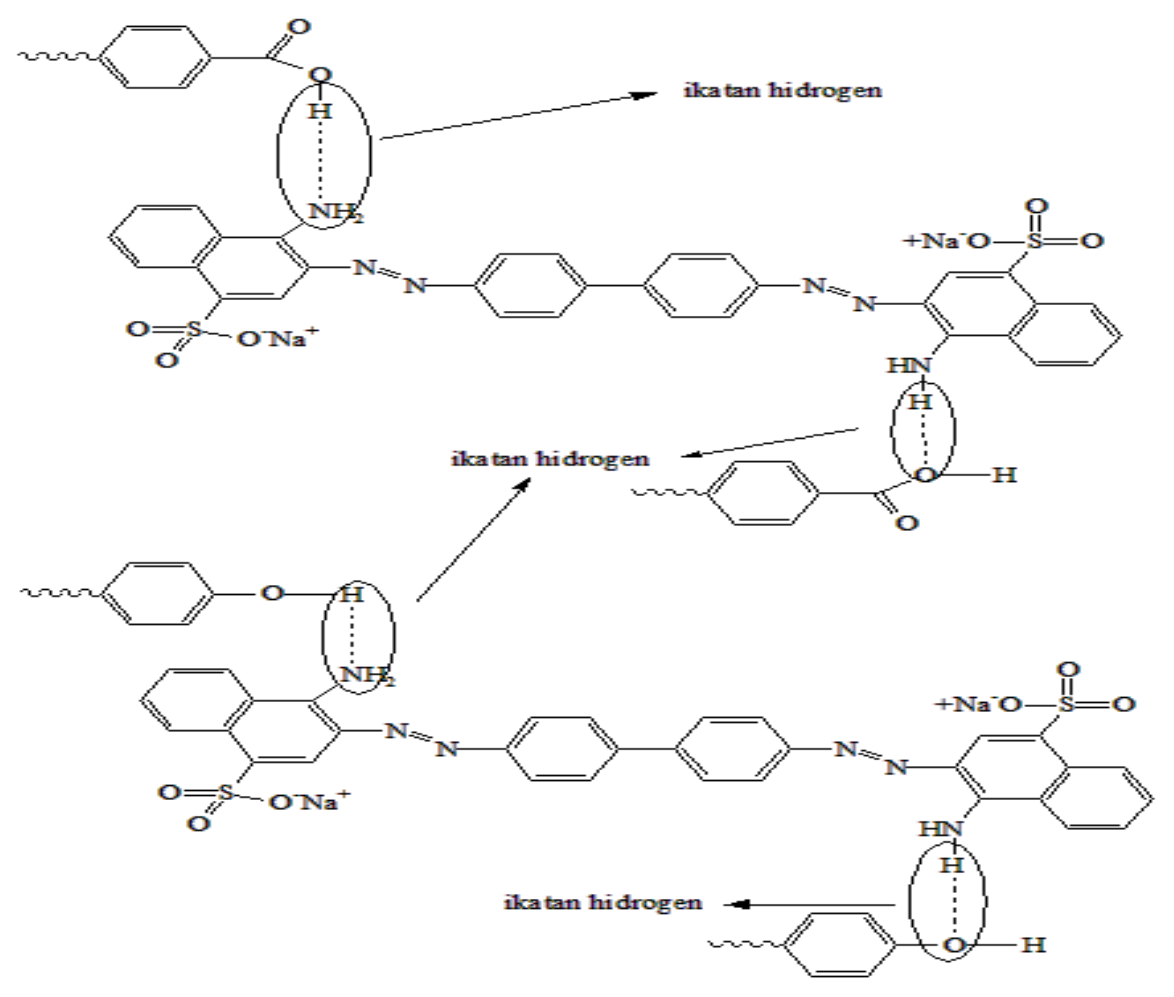

Gambar 6. Ikatan hidrogen antara gugus aktif humin dan congo red (Vinodet $. a l ., 2003)$ 
Molekul, Vol. 3. No. 1. Mei, 2008 : 1 - 9

\section{Isoterm Adsorpsi}

Isoterm

menggambarkan

jumlah zat yang diadsorpsi oleh adsorben atau konsentrasi pada keadaan kesetimbangan dengan tekanan dan temperatur yang tetap (Hidayatulloh et. al, 2002). Ada dua jenis isoterm adsorpsi yang biasanya digunakan untuk mengkarakterisasi adsorpsi dalam sistem lingkungan, yaitu isoterm adsorpsi Langmuir dan Freundlich. Penentuan jenis isoterm adsorpsi digunakan untuk mengetahui apakah adsorpsinya sesuai dengan aturan Langmuir atau sesuai dengan aturan Freundlich.

Isoterm Langmuir

Persamaan isoterm Langmuir adalah

$$
\frac{C}{m}=\frac{1}{b \cdot K}+\frac{C}{b}
$$

Dimana $m$ adalah jumlah adsorbat teradsorpsi per gram adsorben pada konsentrasi $\mathrm{C}, \mathrm{K}$ adalah konstanta kesetimbangan (afinitas adsorpsi), C adalah konsentrasi ion logam saat kesetimbangan dan $\mathrm{b}$ adalah adsorbat yang teradsorpsi pada keadaan jenuh (kapasitas adsorpsi maksimum).

Nilai $R^{2}$ yang diperoleh dari kurva isoterm Langmuir sebesar 0,9796 dengan persamaan $\mathrm{y}=0,0168 \mathrm{x}$ $+0,5659$. Nilai kapasitas adsorpsi maksimum dapat ditentukan dengan menentukan nilai $\mathrm{b}$ dari persamaan diatas dan diperoleh $57,1428 \mathrm{mg} / \mathrm{g}$
Isoterm Freundlich

Persamaan isoterm Freundlich adalah

$\log m=1 / n \log C+\log K$

Berdasarkan perbandingan nilai $\mathrm{R}^{2}$ yang diperoleh dari kedua kurva isoterm adsorpsi, nilai $\mathrm{R}^{2}$ pada kurva isoterm adsorpsi Langmuir lebih besar dibandingkan dengan nilai $\mathrm{R}^{2}$ pada kurva isotherm adsorpsi Freundlich, yang berarti bahwa adsorpsi congo red oleh humin mengikuti persamaan isoterm adsorpsi Langmuir.

\section{KESIMPULAN}

Berdasarkan penelitian ini dapat disimpulkan bahwa :

1. Humin dari tanah hutan damar Desa Ketenger Kecamatan Baturaden mempunyai kadar air sebesar 34,92 \%; kadar abu sebesar 8,65 \%; keasaman total sebesar $475 \mathrm{cmol} / \mathrm{kg}$; kandungan $\mathrm{OH}$ fenolat sebesar $272,5 \mathrm{cmol} / \mathrm{kg}$ serta kandungan gugus karboksilat sebesar 202,5 cmol/ $/ \mathrm{kg}$.

2. Adsorpsi congo red oleh humin dari tanah hutan damar Desa Ketenger Kecamatan Baturaden mempunyai $\mathrm{pH}$ optimum 7 dengan waktu kontak optimum selama 40 menit

3. Isoterm adsorpsi congo red oleh humin dari tanah hutan damar Desa Ketenger Kecamatan Baturaden mengikuti persamaan isoterm adsorpsi Langmuir, dengan kapasitas adsorpsi sebesar 57,14 $\mathrm{mg} / \mathrm{g}$ 


\section{DAFTAR PUSTAKA}

Adamsons, W.A. 1976. Physical Chemistry of Surfaces. Interscience. New York

Allen, S.J and B Koumanova. 2005. Decolourisation of Water/ Wastewater Using Adsorption. Journal of The University of Chemical Technology and Metallurgy. P: 175-192

Crovetto, C. 1997. Building New Organic Soil Throuh Permanent No Till in Old Eroded Chilean soil. Publishing Victor Trucco. Argentina

Day, R.A. and A.L. Underwood. 1991. Quantitative Analysis. Sixth edition. Prentice-Hall International inc. London.

Khopkar, S.M. 2003. Konsep Dasar Kimia Analitik. UI-Press. Jakarta.

Oscik, J. 1982. Adsorption. John Wiley and Sons. Inc. New York

Schnoor, Jerald .L. 1996. Environmental Modeling, Fate and Transport of
Pollutants In Water, Air and Soil. John Wiley and Sons. Inc. New York

Stevenson, F.J. 1982. Humus Chemistry,

Genesis, Composition, Reaction. J.Whiley. New York

SNI. 2002. Metode Pengujian Kadar Air, Kadar Abu dan Bahan Organik Dari Tanah Gambut dan Tanah Organik Lainnya. SNI 13-6793-2002

Tan, K. H 1982. Priciples of Soil Chemistry. Marcel Dekker. New York.

Tan, K. H 1993. Soil Sampling, Preparation and Analysis. Marcel Dekker. New York.

Tan, K. H. 1995. Dasar-dasar Kimia Tanah. Gajahmada University Press. Yogyakarta.

Vinod, V. P. and T. S. Anirudhan. 2003. Adsorption Behaviour of Basic Dyes on the Humic Acid Immobilized Pillared Clay. Springer Netherlands. 